\title{
The Choice of Tactical Approaches to the Implementation of Enterprise Strategy in Terms of Innovative Development
}

\author{
KATERYNA DOROSHKEVYCH ${ }^{1}$, OLEKSANDER MASLAK ${ }^{2}$, ULIANA MOTORNIUK ${ }^{3}$, VOLODYMYR \\ ZHEZHUHA $^{4}$, MARTA TEREBUH ${ }^{5}$, OLGA MALINOVSKA ${ }^{6}$ \\ ${ }^{1}$ Department of management and international business, LVIV POLITECHNIK NATIONAL UNIVERSITY, UKRAINE, \\ E-mail: kateryna.o.doroshkevych@Ipnu.ua \\ 2Department of Foreign Trade and Customs, LVIV POLITECHNIK NATIONAL UNIVERSITY, UKRAINE, \\ E-mail: oleksandr.o.maslak@Ipnu.ua \\ ${ }^{3}$ Department of Foreign Trade and Customs, LVIV POLITECHNIK NATIONAL UNIVERSITY, UKRAINE, \\ E-mail: uliana.i.motorniuk@Ipnu.ua \\ ${ }^{4}$ Department of Foreign Trade and Customs, LVIV POLITECHNIK NATIONAL UNIVERSITY, UKRAINE, \\ E-mail: volodymyr.zhezhukha@Ipnu.ua \\ ${ }^{5}$ Department of Economics of Ukraine, IVAN FRANKO NATIONAL UNIVERSITY OF LVIV, UKRAINE \\ E-mail: terebuchmarta@gmail.com \\ ${ }^{6}$ Department of Management and Economics, IVAN FRANKO NATIONAL UNIVERSITY OF LVIV, UKRAINE, \\ E-mail: olga.malinovska@Inu.edu.ua
}

\begin{abstract}
In order to increase the level of efficiency of strategic management of the enterprise as a result of strategy implementation by means of various tactical approaches, the article investigates methods and models for selecting tactical approaches to strategy implementation: enterprise strategy and tactics tree (S\&T tree), marginal approach to the choice of tactics, hidden Markov model, method of morphological analysis, etc. Critical analysis of the methods has proved the necessity of combining them in order to increase the effectiveness of the mathematical apparatus, which is designed to reduce the subjectivity, which is inherent in heuristic methods (provided by most of the studied methods).

In order to achieve the goals of the article, it is recommended the procedure for choosing tactical approaches to implementing the strategy: definition of the purposes and tasks, information maintenance of process of a choice of the tactical approach; formation of a set of strategic approaches for realization of strategy of the enterprise for what it is possible to use elements of a suffix tree; selection of criteria for acceptability of the tactical approach (Boolean variables that characterize the costs of the enterprise and the implementation of the tactical approach, the level of prices for finished products and services, market capacity in which the company operates, the level of market competition, international economic relations) and their expert evaluation; formation of a table of values of the Boolean function of an acceptable tactical approach to implementing enterprise strategy and evaluating the Boolean vector number; formation of an evaluation scale depending on the set of tactical approaches of the enterprise; selection tactical approach on the recommended scale.

The practical implementation of the recommended procedure at TMC «Lvivholod» Ltd. (the company is one of the leaders in the retail trade of Western Ukraine with more than ten years of experience in retail, it ranks 5th place in the all-Ukrainian ranking of networks by number of outlets) has allowed to choose a tactical approach, which involves the transformation of existing products in the enterprise, the formation of their new features and subspecies that can meet the different needs of consumers, the development of quality characteristics of the enterprise's products, excellent product properties..
\end{abstract}

Keywords: Strategy; Tactics; Tactical approaches; Eligibility criteria; Boolean functions; Innovative development

JEL Classification: O21, O30, L10 


\title{
La Elección de Enfoques Tácticos para la Aplicación de la Estrategia Empresarial en Términos de Desarrollo Innovador
}

\author{
KATERYNA DOROSHKEVYCH ${ }^{1}$, OLEKSANDER MASLAK ${ }^{2}$, ULIANA MOTORNIUK ${ }^{3}$, VOLODYMYR \\ ZHEZHUHA $^{4}$, MARTA TEREBUH ${ }^{5}$, OLGA MALINOVSKA ${ }^{6}$ \\ ${ }^{1}$ Department of management and international business, LVIV POLITECHNIK NATIONAL UNIVERSITY, UKRAINE, \\ E-mail: kateryna.o.doroshkevych@Ipnu.ua \\ ${ }^{2}$ Department of Foreign Trade and Customs, LVIV POLITECHNIK NATIONAL UNIVERSITY, UKRAINE, \\ E-mail: oleksandr.o.maslak@lpnu.ua \\ ${ }^{3}$ Department of Foreign Trade and Customs, LVIV POLITECHNIK NATIONAL UNIVERSITY, UKRAINE, \\ E-mail: uliana.i.motorniuk@Ipnu.ua \\ ${ }^{4}$ Department of Foreign Trade and Customs, LVIV POLITECHNIK NATIONAL UNIVERSITY, UKRAINE, \\ E-mail: volodymyr.zhezhukha@lpnu.ua \\ ${ }^{5}$ Department of Economics of Ukraine, IVAN FRANKO NATIONAL UNIVERSITY OF LVIV, UKRAINE \\ E-mail: terebuchmarta@gmail.com \\ ${ }^{6}$ Department of Management and Economics, IVAN FRANKO NATIONAL UNIVERSITY OF LVIV, UKRAINE, \\ E-mail: olga.malinovska@Inu.edu.ua
}

\section{RESUMEN}

Con el fin de aumentar el nivel de eficacia de la gestión estratégica de la empresa como resultado de la aplicación de la estrategia por medio de diversos enfoques tácticos, el artículo investiga los métodos y modelos de selección de enfoques tácticos para la aplicación de la estrategia: árbol de estrategia y táctica de la empresa (árbol S\&T), enfoque marginal para la elección de tácticas, modelo de Markov oculto, método de análisis morfológico, etc. El análisis crítico de los métodos ha demostrado la necesidad de combinarlos para aumentar la eficacia del aparato matemático, que está diseñado para reducir la subjetividad, inherente a los métodos heurísticos (que proporcionan la mayoría de los métodos estudiados).

Para alcanzar los objetivos del artículo, se recomienda el procedimiento de elección de enfoques tácticos para la aplicación de la estrategia: definición de los propósitos y tareas, mantenimiento de la información del proceso de una elección del enfoque táctico; formación de un conjunto de enfoques estratégicos para la realización de la estrategia de la empresa para lo que es posible utilizar los elementos de un árbol de sufijos; selección de los criterios de aceptabilidad del enfoque táctico (variables booleanas que caracterizan los costes de la empresa y la aplicación del enfoque táctico, el nivel de los precios de los productos terminados y servicios, la capacidad del mercado en el que opera la empresa, el nivel de competencia del mercado, las relaciones económicas internacionales) y su evaluación por expertos; formación de una tabla de valores de la función booleana de un enfoque táctico aceptable para la aplicación de la estrategia de la empresa y evaluación del número del vector booleano; formación de una escala de evaluación en función del conjunto de enfoques tácticos de la empresa; selección del enfoque táctico en la escala recomendada.

La aplicación práctica del procedimiento recomendado en la empresa TMC "Lvivholod" Ltd. (la empresa es una de las líderes en el sector de la construcción) se ha llevado a cabo en el año 2000. (la empresa es uno de los líderes en el comercio minorista de Ucrania Occidental con más de diez años de experiencia en el comercio minorista, ocupa el 5o lugar en el ranking de redes de toda Ucrania por número de puntos de venta) ha permitido elegir un enfoque táctico, que implica la transformación de los productos existentes en la empresa, la formación de sus nuevas características y subespecies que pueden satisfacer las diferentes necesidades de los consumidores, el desarrollo de las características de calidad de los productos de la empresa, excelentes propiedades del product

Palabras claves: Estrategia; Táctica; Enfoques tácticos; Criterios de elegibilidad; Funciones booleanas; Desarrollo innovador

Clasificación JEL: O21, O30, L10 


\section{Introduction}

As you know, strategy and tactics belong to the main categories that ensure the effectiveness of strategic management. Strategy determines the prospects and future state of the organization, and tactics are the approach that ensures its implementation (Kuzmin \& Melnyk, 2013). Tactical actions are reflected in the plans, tasks, actions of employees that contribute to the achievement of strategic goals of the enterprise. The success of enterprise management processes and the effectiveness of the main vectors of its development requires, among other things, ensuring the principle of compliance with the strategy and tactics of the organization (Kirillova, 2012). Let us look at the relationship between these concepts.

Business Strategy is a comprehensive long-term perspective of the enterprise, developed for periods of over one year. Tactics - is a logical continuation of the strategy, which is short-term. The implementation of the strategy can be done in different ways, by choosing the appropriate tactical approaches. They should be combined and applied depending on the situation and factors influencing the company and so on. Thus, in the implementation of the strategy it is possible to form a number of tactical approaches and ensure their choice. According to Gulakova I.I., the choice of strategic approaches is determined by the strategic plan and contains the following essential components: purpose, information and resource provision, tactical actions, tactical positions of the enterprise, etc. (Gulakova, 2004).

Examining the tactical approaches that are available for use by enterprises, it should be noted that they can be classified depending on the criterion of strategic affiliation. According to this, tactical approaches are divided into specific (attached to a particular strategy) and typical (which do not have a strategic affiliation and receive it only in a specific situation at the enterprise) (Lanskikh, 2008).

A balanced strategy can be ensured by applying appropriate methodological approaches to its selection, which are mostly related with using the matrix methods. At the same time, the effectiveness of tactical approaches depends on, on the one hand, their compliance with the company's strategy (provided in the process of their formation and use) (saleem et al 2017). On the other hand, when forming a strategy should take into account the real capabilities of the enterprise in solving strategic problems (Malyarets et al., 2019). Thus, in the process of strategic management should focus on selecting tactical approach to implement the strategy.

As you know, organizations are open systems that interact with the external environment: consume resources and produce finished products (goods, works, services). With the system approach, the organization is a complex object management characterized as deterministic and nondeterministic characteristics and dependencies (Spiryachin \& Burkovsky, 2014). The change in the state of complex objects of management is influenced by both qualitative factors that characterize the change in the current state of a complex object to the necessary, and little-known, uncertain factors, the impact of which should be investigated. Therefore, the change of state of complex objects should be classified as semistructured problems of system analysis and selection and adjustment tactical approaches to strategy implementation requires the use of a scientific approach to implementation.

\section{Material and research methods}

In the scientific literature of technical, medical and economic direction, there are a number of methods for selecting tactical approaches to implementing the strategy in each of their areas of application. Consider the main ones.

Qualitative and empirical methods are used to automatically detect information retrieval tactics following the behavior of network users, which should ensure tactical recognition and reasoning. Most of them require pre-determined tactics for searching and encoding data manually. At the stage of automatic recognition of tactics, the existing methods miss the stage of its comprehension. To eliminate the described shortcomings in the process of performing the tasks, it is recommended to use an approach based on the hidden Markov model. It provides processing of a large amount of 
information and identifying the relationship between information retrieval tactics and individual search actions (Han, Yue \& Daqing, 2013). The application of the hidden Markov model allows to consider complex data structures and to model non-stationary data in which the hidden variables are considered as an element of the Markov chain process. This allows the use of this approach in modeling the processes of strategic management of the enterprise. It should be used the appropriate software. The approach to the choice of tactics which is based on knowledge, involves the implementation of the following stages (Fig. 1): selection of tactical sets with the knowledge base and evaluation of their value using a situational approach; calculation of the coefficient by which the choice of tactics is made by forecasting the costs of their implementation (selective factor analysis); checking the factors that ensured the choice of tactics based on the use of the method of sensitivity analysis (Anda, Dreiem, Sjoberg \& Jorgensen, 2001).

In this approach, the interrelationships between the stages remain are unclear, there is no feedback from the tactics selection processes, as well as the limitations that have determined necessity of applying a boundary approach.

Figure 1. An approach to the choice of tactics based on knowledge (Anda, Dreiem, Sjoberg \& Jorgensen, 2001)

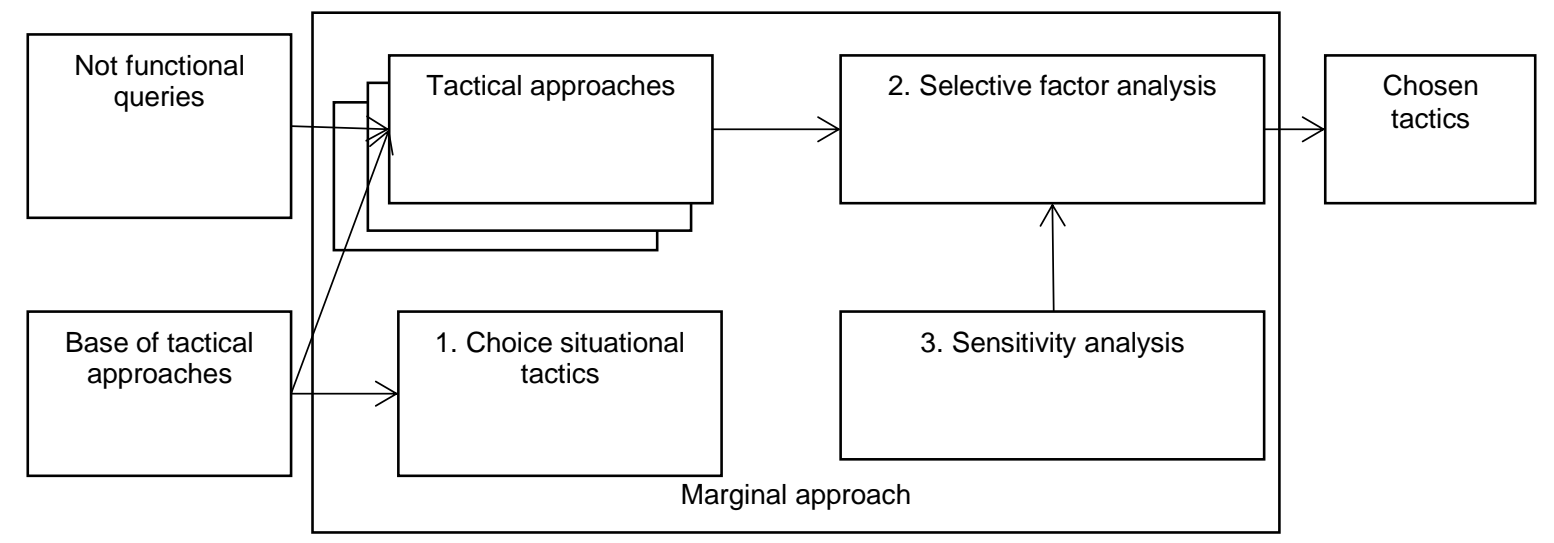

To ensure the selection process is important tactics to ensure its representation and reflection that is realized in the tree structure using strategy and tactics tree (Tree $S \& T$ ) (Hameed, Dobson \& Jackson, 1993; Yeong and Stratton, 2017; Bila at al., 2020). In the practice of enterprise management (in particular, operational management practices) the $S \& T$ tree is considered as a change management tool, it reflects the logical sequence of execution, verification and feedback of the strategy implementation (Fig. 2).

Figure 2. Graphic representation of the tree of strategy and tactics of the enterprise (S\&T tree) (Harmony, 2016)

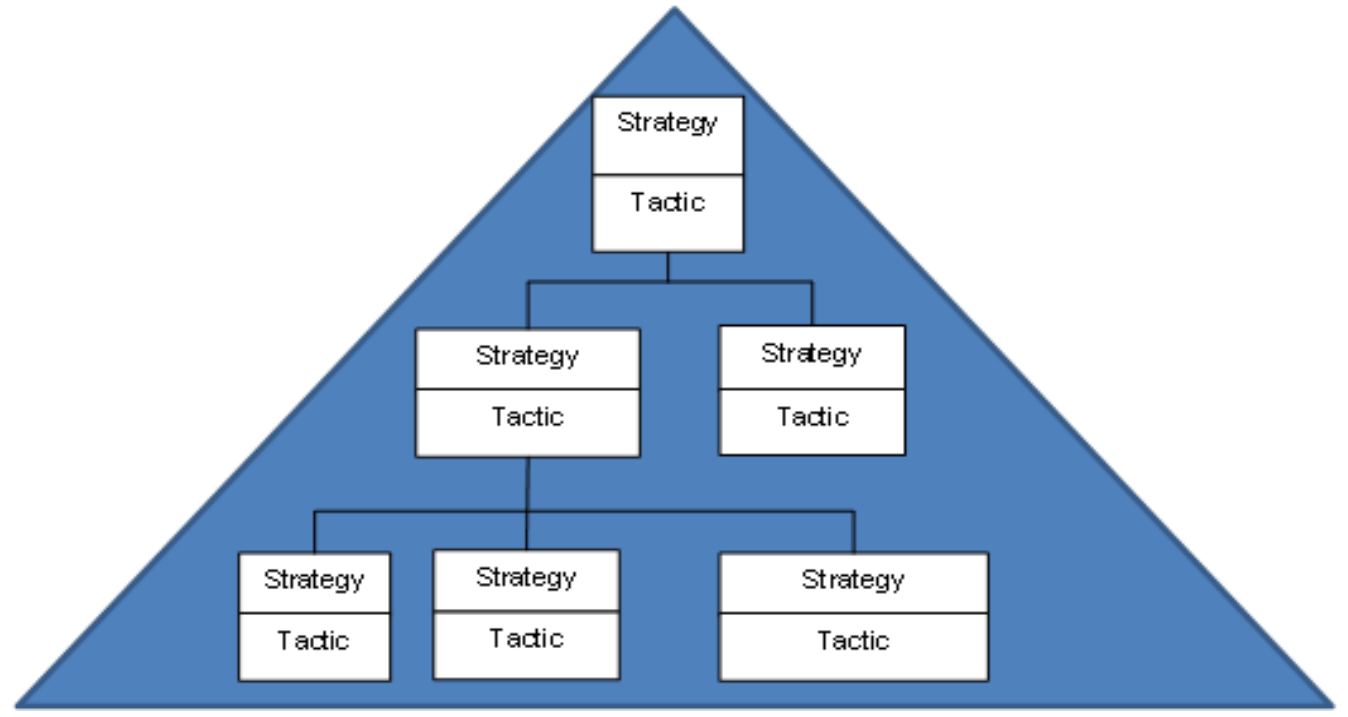


With its help, managers of all levels of management are responsible for compliance with the strategy and tactics of action in the process of making changes in the enterprise. They must justify how the changes, initiated by them, affect the strategy and tactics of higher levels and agreed with them in the process of disseminating the strategic intentions of the enterprise.

As you can see, the tree of strategy and tactics of the enterprise (S\&T Tree) contains information on the strategies of the enterprise at all levels of its management and tactical approaches that are designed to implement these strategies (Fig. 2). However, an important role in the process of forming and using the strategy and tactics tree of the enterprise (S\&T Tree) is given to the management staff of the enterprise, which uses expert assessments.

Also in the process of choosing tactical approaches to the implementation of the strategy it is advisable to use the method of morphological analysis (morphological method). The idea of using the results of morphological analysis of tissues in choosing the optimal treatment strategy of patients was expressed by Hromova V. N. (Hromova, 2011). The morphological method (method of morphological analysis) was developed by F. Zwicky for research in the field of astrophysics, but is used in the field of linguistics, philology, medicine, biology, computer science, economics, management and more (Zwicky \&Wilson, 1967).

The essence of the method is to divide any problem into relatively independent parts, and then to find all possible solutions for the practical implementation of each of the parts (Hrabovetskyi, 2000). This process can be divided into the following components: direct morphological analysis (decomposition (classification) of the studied object or set into components) and morphological synthesis, which involves the study of separated constituent sets and the choice of their optimal in terms of the purpose of the study (Pankratova \&Savchenko, 2008). Thus, morphological analysis involves not a simple decomposition of the problem (phenomena, systems) into components (elements), but also determine the impact of selected elements (components, subproblems, etc.) on the overall problem. This allows you to discard deliberately unnecessary objects (components, solutions) and minimize the number of options that may be subject to technical and economic comparison (Polovinkin, 1988).

It is common to use the method to solve technical, creative and design problems, which include: design of new machines and process equipment; search for new variants of technological processes; finding new ways to use the existing object (product); forecasting the development of technical systems and technologies, etc. (Amelkin et. all, 2010). To implement advanced methods of finding new technical solutions in the early stages of technological preparation of production, it can be used structural - morphological synthesis using the target tree. This method is a development of morphological analysis and involves the use of a structured set of goals of different levels, which also allows us to identify the best possible combinations of component systems in terms of their impact (Litwin, Yashchuk \& Davidkin, 2016). Thus, we argue about the feasibility of using methods of morphological analysis in the formation and selection of tactical approaches to the implementation of enterprise strategy, which can complement the above-described tree of strategy and tactics of the enterprise (S\&T Tree). This will allow more careful selection of tactical approaches to strategy implementation, combining tools to justify management decisions.

Based on the analysis of methodological tools and approaches to justify the strategy and tactics of the enterprise, we can also claim about their diversity (tree of strategy and tactics of the enterprise (S\&T Tree), the marginal approach to the choice of tactics, hidden Markov model, etc.). We also note the necessity of combining them in order to increase efficiency in the application of the mathematical apparatus (saeed et al 2017). The latter is designed to reduce the subjectivity inherent in heuristic methods, which are provided using most of the studied methods.

\section{Results and discussion}

To achieve the outlined goals, we recommend a model of choosing a tactical approach to the implementation of the strategy of innovative development of the enterprise. Its use will ensure compliance with tactical approaches to the company's strategy, which is correlated with the mission 
and goals of the enterprise. Properly chosen and timely regulated tactical approaches will increase the effectiveness of the organization and its strategy.

The model of choosing a tactical approach to the implementation of the strategy of innovative development of enterprises involves identifying those tactics that meet the criteria of acceptability. Based on the study of the practice of innovative development of enterprises, the criteria for the acceptability of tactical approaches are: the costs of the enterprise and the implementation of the tactical approach $\left(\mathrm{X}_{1}\right)$; the level of prices for finished products and services $\left(\mathrm{X}_{2}\right)$; the capacity of the market in which the company operates $\left(\mathrm{X}_{3}\right)$; level of market competition $\left(\mathrm{X}_{4}\right)$; international economic relations $\left(\mathrm{X}_{5}\right)$.

Taking into account the eligibility criteria $\left(\mathrm{X}_{1}, \ldots, \mathrm{X}_{5}\right)$, the model of choosing a tactical approach to strategy implementation $\left(T_{a p}\right)$ took the form of an $\mathrm{n}$-digit Boolean function (function of two-valued logic):

$$
\left\{\begin{array}{c}
T_{a p_{o p t}}=f\left(Z_{2}^{n} \rightarrow Z_{2}\right),(n=5) \\
T_{a p_{o p t}} \in T_{a p}
\end{array},\right.
$$

where $T_{a p_{\text {opt }}}$ - an acceptable tactical approach to implementing the company's strategy in terms of innovative development;

$T_{a p}$ - possible tactical approaches on realization of strategy of the enterprise in the conditions of innovative development, formed as a result of construction of a suffix tree (Doroshkevych, Ivasyuk \& Iskiv, 2020);

$Z_{2}$ - vector of Boolean values of the criteria for the acceptability of tactical approaches.

All variables of the Boolean function are also Boolean variables that acquire values $(-1 ; 0 ; 1)$. However, the elements of the values of the set (vector) $Z_{2}=\{0 ; 1\}$, because in the theory of Boolean functions they can acquire only two values. In this case, the vector of the form $\widetilde{X}=$ $\left(X_{1}, X_{2}, X_{3} \ldots \ldots . X_{n}\right), X_{i} \in Z_{2}, i=\overline{1, m}$.

Based on these dependences, the vector $Z{ }_{2}^{n}$ contains $n$ factors $\left(Z_{2}^{1}, Z_{2}^{2}, Z_{2}^{3} \ldots . . Z_{2}^{n}\right)$. In addition, in order to choose a tactical approach to the implementation of the strategy, you can determine the number of the Boolean vector $\left(Z_{2}^{n}\right)$, which we will use as a resulting indicator, choosing a suitable tactical approach.

To calculate it, use the formula:

$$
N(\tilde{X})=X_{1} * 2^{n-1}+X_{2} * 2^{n-2}+\cdots+X_{n-1} * 2+X_{n}
$$

The equality is fulfilled:

$$
0 \ll N(\tilde{X}) \ll 2^{n}
$$

The range of values of the Boolean function is finite, it can be set using tables of values (Table 1 ).

As has been already mentioned, $Z_{2}=\{0 ; 1\}$, which is the Boolean constants.

In order to select acceptable tactical approaches to the implementation of the strategy of innovative development of the enterprise, we will investigate the acquisition of these values by the criteria $\widetilde{\mathrm{X}}=\left(X_{1}, X_{2}, X_{3} \ldots \ldots . X_{n}\right), n=(\overline{1,5})$.

The first criterion is the cost of the enterprise to implement a tactical approach $\left(X_{1}\right)$. Costs are one of the main criteria influencing the implementation decisions, etc. or other tactical approach or management decision in general. If the company has a significant amount of financial resources for the implementation of the complex, which are provided by the tactical approach, the variable becomes $\{0\}$. It means virtually unlimited financial capabilities of enterprises in the implementation of its tactical approaches. If the company does not have sufficient financial resources and its financial condition cannot be classified as stable, the variable should be evaluated as $\{1\}$. 
Kateryna Doroshkevych, Oleksander Maslak, Uliana Motorniuk, Volodymyr Zhezhuha, Marta Terebuh,

Olga Malinovska

Table 1. The table of values of the Boolean function of the acceptable tactical approach on realization of strategy of the enterprise in the conditions of innovative development

\begin{tabular}{|c|c|c|c|c|c|c|}
\hline \multirow{2}{*}{ № } & \multicolumn{5}{|c|}{ Values of Boolean variables } & \multirow{2}{*}{$N(\tilde{X})$} \\
\hline & $\mathrm{X}_{1}$ & $\mathrm{X}_{2}$ & $\mathrm{X}_{3}$ & $\mathrm{X}_{4}$ & $\mathrm{X}_{5}$ & \\
\hline 1 & 0 & 0 & 0 & 0 & 0 & 0 \\
\hline 2 & 0 & 0 & 0 & 0 & 1 & 2 \\
\hline 3 & 0 & 0 & 0 & 1 & 1 & 6 \\
\hline 4 & 0 & 0 & 1 & 1 & 1 & 14 \\
\hline 5 & 0 & 1 & 1 & 1 & 1 & 30 \\
\hline 6 & 1 & 1 & 1 & 1 & 1 & 62 \\
\hline 7 & 0 & 1 & 1 & 0 & 1 & 26 \\
\hline 8 & 0 & 0 & 1 & 1 & 1 & 14 \\
\hline 9 & 0 & 0 & 0 & 1 & 1 & 6 \\
\hline 10 & 1 & 0 & 1 & 0 & 1 & 42 \\
\hline 11 & 0 & 0 & 1 & 0 & 1 & 10 \\
\hline 12 & 0 & 0 & 1 & 0 & 0 & 8 \\
\hline 13 & 0 & 1 & 0 & 0 & 0 & 16 \\
\hline 14 & 0 & 0 & 1 & 1 & 0 & 12 \\
\hline 15 & 0 & 0 & 0 & 1 & 0 & 4 \\
\hline 16 & 1 & 0 & 1 & 0 & 0 & 40 \\
\hline 17 & 0 & 1 & 1 & 0 & 0 & 24 \\
\hline 18 & 0 & 1 & 1 & 1 & 0 & 28 \\
\hline 19 & 0 & 1 & 1 & 1 & 1 & 30 \\
\hline 20 & 1 & 0 & 1 & 1 & 0 & 44 \\
\hline 21 & 0 & 0 & 0 & 1 & 1 & 6 \\
\hline 22 & 0 & 1 & 0 & 1 & 0 & 20 \\
\hline 23 & 0 & 1 & 0 & 1 & 1 & 22 \\
\hline 24 & 1 & 0 & 1 & 1 & 1 & 46 \\
\hline 25 & 1 & 0 & 0 & 1 & 1 & 38 \\
\hline
\end{tabular}

When choosing tactical approaches should consider the level of costs of their implementation, and choose those with low levels.

The level of prices for finished products and services - variable $\left(\mathrm{X}_{2}\right)$ characterizes the demand for products (services) of the enterprise as a criterion for the acceptability of tactics when market conditions change due to inflation. As prices rise, buyers' costs are known to increase. For some buyers, this factor is crucial when deciding to buy goods and they are even able to switch to the consumption of other goods. If this situation is typical for the company and its products have a low level of differentiation and demand is sensitive to changes in the price level, the variable should be evaluated as $\{0\}$. The opposite situation in which the demand for products of enterprises is not significantly affected by the price level, consumers are committed to the brand of the enterprise, the product has a high level of differentiation allows you to estimate the variable at $\{1\}$.

The capacity of the market in which the company operates $\left(\mathrm{X}_{3}\right)$ as the potential sales of products (goods and services) of the company at the current level of prices and competition among manufacturers affects the choice of its tactical approaches. With a large market capacity, the variable takes the value $\{1\}$, because the company should not take aggressive action to increase its share and can be limited to one of the tactical approaches. For low market capacity, accompanied by increased competition (in particular, price), the variable should be evaluated $\{0\}$, which requires many tactical approaches to implement the company's strategy in terms of innovative development.

The level of market competition $\left(\mathrm{X}_{4}\right)$ has an impact on the choice of tactical approaches as follows. A moderate level of market competition allows the company to implement more passive market strategies of interaction, focus on stabilizing its own position in the already acquired market niche. In 
this situation, the variable can be assessed as $\{1\}$, In this situation, the variable can be assessed as 1 , because the tactical techniques for implementing the company's strategy can be individual actions to maintain its own market position of the company. If market competition is high, the company should apply an aggressive action plan in the fight for its customers and pay attention to the implementation of a set of strategic approaches and the variable becomes $\{0\}$.

International economic relations $\left(\mathrm{X}_{5}\right)$ and the level of development of their forms and organizational types (international trade in the form of exports, imports, international joint ventures and activities of transnational organizations, international alliances, international cooperation between cities, etc.) influence the choice of tactical approaches as follows. With a high level of development of international economic relations, various forms of cooperation are available for the enterprise, as well as an open foreign market, and the realization of various forms of cooperation is possible. This allows you to optimize costs, increase demand, increase production, and more. Under these conditions, the variable can be evaluated as $\{1\}$. The value $\{0\}$ should be given to the variable if the enterprise does not have established international economic relations and does not realize any benefits of international activities.

Table 2. Table of ordered values of the Boolean function of an acceptable tactical approach to the implementation of enterprise strategy in terms of innovative development

\begin{tabular}{|c|c|c|c|}
\hline $\begin{array}{c}\text { № of } \\
\text { combination }\end{array}$ & $N(\tilde{X})$ & $\begin{array}{c}\text { The level of the Boolean } \\
\text { function }\end{array}$ & Tactical approaches \\
\hline 1 & 0 & \multirow{11}{*}{ Low } & \multirow{11}{*}{ Tactical approach 1} \\
\hline 2 & 2 & & \\
\hline 15 & 4 & & \\
\hline 3 & 6 & & \\
\hline 9 & 6 & & \\
\hline 21 & 6 & & \\
\hline 12 & 8 & & \\
\hline 11 & 10 & & \\
\hline 14 & 12 & & \\
\hline 4 & 14 & & \\
\hline 8 & 14 & & \\
\hline 13 & 16 & \multirow{8}{*}{ Average } & \multirow{8}{*}{ Tactical approach 2} \\
\hline 22 & 20 & & \\
\hline 23 & 22 & & \\
\hline 17 & 24 & & \\
\hline 7 & 26 & & \\
\hline 18 & 28 & & \\
\hline 5 & 30 & & \\
\hline 19 & 30 & & \\
\hline 25 & 38 & \multirow{5}{*}{ Level above average } & \multirow{5}{*}{ Tactical approach 3} \\
\hline 16 & 40 & & \\
\hline 10 & 42 & & \\
\hline 20 & 44 & & \\
\hline 24 & 46 & & \\
\hline 6 & 62 & High & Tactical approach 4 \\
\hline
\end{tabular}

To choose a tactical approach based on the results of evaluating the eligibility criteria $\left(\mathrm{X}_{1}, \ldots, \mathrm{X}_{5}\right)$, using the model (1) and the formed table of values of the Boolean function (Table 1), it should be formed a range of values of the function. Its scale depends on the set of tactical approaches of the enterprise and can be determined using different levels. 
We use a four-level rating scale, which in the range of values $\{0 ; 1\}$, contains the following limits: $\{0 ; 0,25\}$ - low level $\quad\{0,25 ; 0,5\}$ - average; $\{0,51 ; 0,75\}$ - level above average; $\{0,76 ; 1\}-$ high level. It should be applied if the company has formed 4 tactical approaches. Based on the maximum number of the Boolean vector, the range of values of the Boolean function will look like:

$$
\left\{\begin{array}{c}
0-15 \text { low level; } \\
16-31 \text { average level } \\
32-46 \text { level above average; } \\
47-62 \text { high level. }
\end{array}\right.
$$

We organize the values of the table of Boolean values of variables and levels of Boolean vector (Table 2).

\section{Experimental}

The practical implementation of the approach took place on the basis of TMC «Lvivholod» Ltd., which has a set of tactics of the optimal costs strategy implementation in terms of innovative activities of the enterprise (Table 3).

Having made an expert assessment of the criteria of acceptability of tactical approaches for TMC "Lvivholod» Ltd., the Boolean function took the form: $\widetilde{f}=(0 ; 1 ; 0 ; 0 ; 1)$. Such expert assessments were obtained considering that the company is one of the leaders in the retail trade of Western Ukraine with more than ten years of experience in this field.

Table 3. Tactics of the optimal costs strategy implementation in terms of innovative activities of TMC «Lvivholod» Ltd.

\begin{tabular}{|l|l|}
\hline \multicolumn{1}{|c|}{$\begin{array}{c}\text { Tactical } \\
\text { approaches }\end{array}$} & \multicolumn{1}{c|}{ The essence } \\
\hline 1 & $\begin{array}{l}\text { Focus on activities to reduce production costs, develop subtypes of products } \\
\text { with different functional characteristics, improve the quality of products and } \\
\text { their properties that ensure their difference from competing products }\end{array}$ \\
\hline 2 & $\begin{array}{l}\text { Transformation of existing products at the enterprise, formation of their new } \\
\text { signs and subspecies which are capable to satisfy various needs of } \\
\text { consumers, development of qualitative characteristics of the goods of the } \\
\text { enterprise, excellent properties of production }\end{array}$ \\
\hline 3 & $\begin{array}{l}\text { Improving the quality of enterprise products, improving (forming) its unique } \\
\text { properties }\end{array}$ \\
\hline 4 & $\begin{array}{l}\text { Concentrating the company's efforts on the uniqueness of its products and } \\
\text { services, ensuring their difference from the goods offered to the market by } \\
\text { competitors }\end{array}$ \\
\hline
\end{tabular}

Note: the table was formed using suffix tree elements (Doroshkevych, Ivasyuk \& Iskiv, 2020)

According to the number of outlets, it ranks 5 th in the all-Ukrainian ranking of networks. The financial position of the company is satisfactory and allows it to invest in the implementation of complex tactical approach to implement the strategy. TMC «Lvivholod» Ltd. produces products under the Kuharochka brand, which is popular among the population of the region, and the goods are not sensitive to changes in market prices (in particular due to the wide range of products and an extensive network). The market is quite large, but is characterized by a significant level of competition. The company is a participant in international economic relations, which confirms the receipt of a loan from the European Bank for Reconstruction and Development (EBRD) in 2017 for UAH 135 million for a period of 6 years. The loan amount is intended for the development of the network of self-service stores "Rukavychka». The company also passed another recertification audit and moved to a new version of the international standard ISO 9001: 2015. It is a quality management system, the certification of which guarantees that the company controls the quality of meat and fish semi-finished products, as well as carries out careful quality control of cereal packaging. At the same time, the company continued the international standard ISO 22000: 2005. This is a food safety management 
system. Thus, the company guarantees consumers safe and quality raw materials, impurities and components used in production.

Using the data in table. $1, N(\tilde{X})=18$, which corresponds to the average level of the Boolean function, for which you should choose tactics that involve the transformation of existing products in the enterprise, the formation of their new features and subspecies that can meet different consumer needs, development of quality characteristics and excellent product properties.

\section{Conclusions}

Summarizing the results of the study, we can form the following procedure for selecting tactical approach to implementing the strategy: definition of goals and objectives, information support of the process of choosing a tactical approach; formation of a set of strategic approaches for realization of strategy of the enterprise for what it is possible to use elements of a suffix tree; selection of criteria for acceptability of the tactical approach (Boolean variables) and their expert evaluation formation of a table of values of the Boolean function of an acceptable tactical approach to the implementation of enterprise strategy and evaluation of the Boolean vector number; formation of an evaluation scale depending on the set of tactical approaches of the enterprise; choice of tactical approach on the recommended scale.

In further research, attention should be paid to the evaluation of tactical approaches and their compliance with the company's strategy.

\section{References}

1. Kuzmin, O. \& Melnyk, O. (2003). Fundamentals of Management: Tutorial. Kyiv: Akademvydav. 416 p.

2. Kirillova, N. N. (2012) Communication strategies and tactics from the perspective of moral categories. Bulletin of NSTU im. R.E. Alekseeva. «Upravlenie v socialnyh sistemah. Kommunikativnye tehnologii». 26-33. URL:https://cyberleninka.ru/article/n/kommunikativnyestrategii-i-taktiki-s-pozitsii-nravstvennyh-kategoriy

3. Gulakova, I. I. (2004). Communication strategies and tactics of speech behavior in a conflict situation of communication. Abstract of the dissertation for the degree of candidate of philological sciences. Specialties: 10.02.01 - Russian language, 10.02.19 - language theory. Oryol. Oryol State University. URL:https://static.freereferats.ru/_avtoreferats/01002624100.pdf

4. Lanskikh, A. V. (2008). Speech Behavior of Reality Show Participants: Communication Strategies and Tactics. Abstract of the dissertation for the degree of candidate of philological sciences. Specialty 10.02.01 - Russian language. Yekaterinburg. State educational institution of higher professional education "Ural State University named after A.M. Gorky" URL:https://elar.urfu.ru/bitstream/10995/1191/1/urgu0587s.pdf

5. Spiryachin, A. A. \& Burkovsky, V. L. (2014). Intelligent decision-making system in the context of choosing tactics for the treatment of chronic diseases based on cloud technologies. Bulletin of Voronezh State Technical University. URL: https://cyberleninka.ru/article/n/intellektualnayasistema-prinyatiya-resheniy-v-usloviyah-vybora-taktiki-lecheniya-hronicheskih-zabolevaniy-naosnove-oblachnyh

6. Han, S., Yue, Z., \& Daqing, H. (2013). Automatic detection of search tactic in individual information seeking: A Hidden Markov Model approach. iConference 2013 Proceedings. 712-716. doi:10.9776/13330

7. Anda, B., Dreiem, D., Sjøberg, D.I.K., Jørgensen, M. (2001). Estimating software development effort based on use cases - Experiences from industry. In M. Gogolla, C. Kobryn (Eds.): UML 2001 - The Unified Modeling Language. Modeling Languages, Concepts, and Tools, 4th Int'l Conference. Springer-Verlag LNCS 2185, 487-502. 
8. Hameed-AI L., Dobson P. \& Jackson P. (1993). The Strategy and Tactic (S\&T) Tree for Achieving the Treacy and Wiersema. Strategic Choices ECU Business Doctoral and Emerging Scholars Colloquium. 2016. 2 December 2016.

9. Bila, O., Gontareva, I., Babenko, V., Kovalenko, O. \& Gliebova., N. (2020). Organizational and Methodological Guidelines for Training Education Managers to Implement the Strategy of Corporate Social Responsibility. International journal of circuits, systems and signal processing. 14, 679-685. https://doi.org/10.46300/9106.2020.14.87

10.Saeed, S., Shaikh, A., Memon, M. A., Memon, M. H., Abassi, F. A., \& Naqvi, S. M. R. (2017). Implementation of failure enterprise systems in organizational perspective framework. International journal of advanced computer science and applications, 8(5), 54-63.

11.Yeong, A. \& Stratton R. (2017). Capturing action research knowledge through Strategy and Tactic (S\&T) tree. In: EurOMA 2017: 24th International Conference the European Operations Management Association, Heriot-Watt University, Edinburgh, 1-5 July 2017. URL: http://irep.ntu.ac.uk/id/eprint/31749/

12. "What is Strategy \& Tactic Trees?" (2016). Harmony. URL: https://www.harmonytoc.com/What-IsTOC-Strategy-and-Tactic-Trees [Accessed 12th December 2016].

13.Khromova, V.N. (2011). Morphological substantiation of the choice of tactics for the treatment of recurrent ligature complications of the anterior abdominal wall. Fundamentalnye issledovanija, 102, 400-402; URL: http://www.fundamental-research.ru/ru/article/view?id=28833

14.Zwicky F. \& Wilson A.G. (1967) New Methods of Thought and Procedure. -Contributions to the Symposium on Methodologies, Pasadena, May 22-24.

15.Saleem, K., Shahzad, B., Orgun, M. A., Al-Muhtadi, J., Rodrigues, J. J., \& Zakariah, M. (2017). Design and deployment challenges in immersive and wearable technologies. Behaviour \& Information Technology, 36(7), 687-698.

16. Hrabovetskyi, B.le. (2000). Fundamentals of economic forecasting: textbook. Vinnytsia: VF TANG, $209 \mathrm{p}$.

17.Pankratova, N. D. \& Savchenko, I. O. (2008). Stagnation of the method of morphological analysis to the tasks of technological transfer. Science of the Chornomorsk State University of the Name of Peter Mohyla. Issue: Computer technologies. Vol. 90, 77, 6-13. URL: http://nbuv.gov.ua/UJRN/Npchduct_2008_90_77_3

18. Polovinkin, A. I. (1988). Fundamentals of engineering creativity: manual. for students of higher tech. study. Establishments. M.: Mashinostroenie. 368 p.

19.Amelkin, V.I. at al. (2010). Technical creativity of students. Textbook. Kyiv: Tsentr uchbovoi literatury, $458 \mathrm{p}$.

20.Malyarets, L.M., Babenko, V.O., Nazarenko, O.V., Ryzhikova, N.I. (2019). The Modeling of Multicriteria Assessment Activity in Enterprise Management, Int. J Sup. Chain. Mgt, vol. 8, no. 4, pp. 9971004. http://ojs.excelingtech.co.uk/index.php/IJSCM/article/view/3342

21.Litwin, O., Yashchuk, I. \& Davidkin, I. (2016). Structural-morphological synthesis clamping lathes cartridges. Collection of abstracts of the $\mathrm{V}$ International scientific and technical conference of young scientists and students "Actual problems of modern technologies", November 17-18. T.: TNTU, 1, 252-253.

22.Doroshkevych K.O., Ivasyuk, V.V. \& Iskiv, O.V. (2020). Strategy and tactics of innovative development of enterprises: essence and interrelation of concepts. Business Inform. 2. 88-94. https://doi.org/10.32983/2222-4459-2020-2-88-94 